\title{
The development of biodegradable hemostatic and absorbable sponges containing chlorhexidine digluconate and their in vitro characterization-A QbD approach
}

\author{
Bohdana Pavliuk $^{1 *}$ (D), Mariana Chubka ${ }^{2}$ (D), Taras Hroshovyi ${ }^{1}$ (D), Mariana Demchuk ${ }^{1}$ (D), Iryna Stechyshyn ${ }^{1}$ (D) \\ ${ }^{1}$ Horbachevsky Ternopil National Medical University, Department of Pharmacy Management, Economics and Technology, Ternopil, Ukraine. \\ ${ }^{2}$ Horbachevsky Ternopil National Medical University, Department of Pharmacy, Ternopil, Ukraine.
}

\section{ARTICLE INFO \\ Received on: 18/07/2021 \\ Accepted on: 19/09/2021 \\ Available Online: 05/02/2022}

Key words:

Medical sponge, quality

by design, technology,

experimental design.

\begin{abstract}
Medical sponges are one of the most common tools used in various fields of medicine and are used to close wound surfaces in burns and trophic ulcers, showing absorbent and antiseptic properties, and stimulate tissue regeneration. The aim of this study was to optimize the composition of medical sponges with chlorhexidine digluconate based on a material of natural origin - xenoderma. The central composite design was used to establish the relationship between independent variables such as quantities of medical gelatin, propyleneglycol, and formaldehyde and dependent variables such as $\mathrm{pH}$, the percentage of water absorption, the degree of in vitro degradation, thickness, and the time of complete dissolution, in order to obtain the optimal formulation using Response Surface Methodology. Using the concept of Quality by Design, the desired quality target product profile, critical quality attributes, risk assessment by Failure Mode Effects Analysis was determined that the number of excipients affects the pharmaco-technological parameters. It was found that sponges that contain $2 \%$ medical gelatin, $1 \%$ propyleneglycol, and $0.75 \%$ formaldehyde, are the best in composition, in terms of $\mathrm{pH}$, the percentage of water absorption, the degree of in vitro degradation, thickness, the time of complete dissolution, in comparison with all other compositions.
\end{abstract}

\section{INTRODUCTION}

The pharmaceutical industry is constantly looking for ways to ensure and improve the safety, quality, and efficiency of products. For this purpose, the principles of the scientific and technical approach to Quality by Design $(\mathrm{QbD})$ are used, which by reducing its possible variations improves the understanding of the technological process and provides the ability to manage it, while requiring in-depth knowledge of production technologies of a particular dosage form (Ohage et al., 2016; Mogal, 2016). QbD involves the analysis and control of all possible risks, assuming that each technological step of the process is a source of possible risk or changes. QbD describes an approach to pharmaceutical development that involves the development of composition and

*Corresponding Author

Bohdana Pavliuk, Horbachevsky Ternopil National Medical University, Ternopil, Ukraine.E-mail: bohdana.vons@gmail.com technology and production to control the established product quality (Beg et al., 2019; Suciu et al., 2018). Recently, the concept of QbD has become increasingly important in the development and production of medicines. $\mathrm{QbD}$ is recommended as one of the methods to improve the quality of pharmaceutical products by the Food and Drug Administration and the European Medicines Agency (Patwardhan et al., 2017; Tefas et al., 2018).

One of the essential tools of QbD in the development of optimized products and processes is "Design of Experiment (DoE)," which is based on the use of experimental designs (Budniak et al., 2020; Demchuk et al., 2018). Recommendations related to mathematical models are used to ensure the establishment and use of knowledge of drug technology independently and in an integrated manner (Politis et al., 2017; Sylvester et al., 2018).

There are currently several documents (of a recommendatory manner) that help to ensure the proper quality of QbD: ICH Q8 “Pharmaceutical Development,” ICH Q9 “Quality Risk Management," and ICH Q10 "Pharmaceutical Quality 
System", as well as the use of Process Analytical Technology or Quality by Testing (ICH 2005; ICH 2008; ICH 2009).

Today, the creation of drugs or medical devices using QbD improves quality, controls risks, and is an integral part of the development of drugs in nonpharmacopoeias dosage forms (Porfire et al., 2017). Examples of such forms are medical sponges, which have wide practical application in various fields of medicine: in surgery, they are used to close wound surfaces in burns and trophic ulcers, showing absorbent and antiseptic properties, and stimulate tissue regeneration (Pavliuk et al., 2020). For example, the use of a dry sponge during surgery provides the absorption of large amounts of fluid, and after the operation, such a sponge dissolves (Liu et al., 2018; Marushchak et al., 2017; Pavliuk et al., 2020). It is currently believed that hemostatic and absorption effects are associated with the porosity of the sponges and their ability to absorb blood or exudate from the wound surface; they restore the integrity of damaged blood vessels and accelerate the recovery of damaged epidermal tissues (Azuma et al., 2015). Sponges exhibit bactericidal, antiseptic, antimicrobial, regenerating, tonic, and absorbent properties and purposefully act on the focus of pathology (Pavliuk et al., 2020). By method of application, sponges are divided into antiseptic, absorbent, hemostatic, vaginal, and rectal.

Since 2000, many studies have been conducted on the development of new hemostatic and absorbent agents, and there is more and more evidence of their effectiveness in comparison with conventional gauze bandages (Konstantelias et al., 2016).

Therefore, the aim of this work was to develop and optimize the composition of a structured medical sponge based on a material of biological origin, namely, xenoderm, which is enriched with macro- and micronutrients, amino acids, and chlorhexidine digluconate $(1 \%)$ as the active pharmaceutical ingredient (API), using $\mathrm{QbD}$ at each stage of technological formation (Leonard et al., 2016; Lytvynyuk et al., 2016; Pavliuk et al., 2020; Vons et al., 2018).

\section{MATERIALS AND METHODS}

\section{Materials}

Crushed substrate of cryolyophilized xenoderm (LLC "Institute of Biomedical Technologies," Ternopil, Ukraine), chlorhexidine digluconate solution 20\% ("Sigma-Aldrich," USA), and excipients, including medical gelatin, formaldehyde ("Sigma-Aldrich", USA), and propylene glycol ("BASF Global," Germany), were used.

\section{Methods}

\section{Preparation of medical sponges}

In the xenoderm water extract, the medical gelatin [with different concentrations according to the central composite circumscribed (CCC) plan] was left at $37^{\circ} \mathrm{C}$ for swelling and dissolution. Then, the remainder of the xenoderm water extract was added to the gelatin solution by parts, with constant stirring until foam formation. To prepared solutions of xenoderm water extract with medical gelatin, the formaldehyde in the different concentrations was added (according to the CCC plan) to provide cross-linking. To the resulting mixtures, it was added a $1 \%$ chlorhexidine digluconate solution. The mixtures were foamed to form a stable foam that increased 2-3 times in volume. The resulting solution was poured out into the cooled aluminum molds (size 15 * $7 \mathrm{~cm} / 100 \mathrm{ml}$ ) and left for $2-3$ hours at temperature $20^{\circ} \mathrm{C}-22^{\circ} \mathrm{C}$ to provide cross-linking of the gelatin with formaldehyde and to form a framework. Thereafter, the solutions were frozen in liquid nitrogen and lyophilized during 18-20 hours (7-8 hours at temperature $-30^{\circ} \mathrm{C} \pm 0.5^{\circ} \mathrm{C}, 4-5$ hours at temperature $+30^{\circ} \mathrm{C} \pm$ $0.5^{\circ} \mathrm{C}$, and $6-7$ hours at temperature $+35^{\circ} \mathrm{C} \pm 0.5^{\circ} \mathrm{C}$ ). The finished dry product (medical sponge) was cut into plates of various sizes and packed in parchment bags.

Using the assessment of the quality target product profile (QTPP), the determination of the quality and efficiency of the developed medical tool was obtained, conducting a preliminary set of quality indicators that must be achieved to guarantee the desired quality, taking into account safety and efficiency. Table 1 presents the QTPP for medical sponges with chlorhexidine digluconate. In addition to defining product design requirements, QTPP will help determine quality indicators, organoleptic properties, scope, and shelf life.

\section{The critical quality attribute (CQA)}

CQA identifies features/properties that should be within the appropriate requirements, distribution, or range to ensure the required quality of medical sponges with chlorhexidine digluconate and that are typically associated with APIs, excipients, intermediates (materials during the process), and the finished product. Table 2 shows the CQAs for medical sponges with chlorhexidine digluconate.

\section{Risk assessment by failure mode effects analysis (FMEA)}

The overall risk assessment (ORA) is shown in the Ishikawa diagram (Fig. 1), which contains all process parameters that may affect or generate errors regarding the quality of the final product. The priority of critical quality indicators of sponges with chlorhexidine digluconate $(1 \%)$ meets three criteria, which were evaluated on a scale (points) from 1 to 5: O: frequency of occurrence (5: for common cases, 4: for probable, 3: there is a possibility of occurrence, 2: for remote, and 1: for impossible cases); S: severity (5: catastrophic, 4: critical, 3: serious, 2: minor, and 1: insignificant); D: the ability to detect (5: impossible or difficult to detect, 4: detected with low probability, 3: moderately detected, 2: easily detected, and 1: very easily detected). Each of the critical process parameters (CPP) and each critical material characteristic (CMC) was evaluated according to these three criteria. The risk/failure priority number (RPN) was calculated by the following formula: $\mathrm{RPN}=O \times S \times D$ (Table 3 ).

$D o E$

Software for optimizing the composition and technology of Design-Expert trial version 12.0.0 (Ease Inc., Minneapolis, $\mathrm{MN}$ ) was used to build the experimental design. In order to study the influence of quantitative factors on the pharmaco-technological parameters of medical sponges, three excipients were selected, namely medical gelatin, propylene glycol, and formaldehyde. The list of quantitative factors and their levels, which were studied in the development of the optimal composition and technology of medical sponges, are presented in Table 4.

The study of selected factors was carried out using a symmetric rotatable composite plan of the second order (CCC). 
Table 1. QTPP of medical sponges.

\begin{tabular}{|c|c|c|}
\hline Quality attribute & Characteristics & Justification \\
\hline Dosage form & Sponge (structured) medical & Intended for external and internal use, closing \\
\hline Application method & Local & $\begin{array}{c}\text { wounds and ulcers of various etiologies, and } \\
\text { stopning surgical bleeding }\end{array}$ \\
\hline API & Chlorhexidine digluconate $1 \%$ & \\
\hline Indication & $\begin{array}{l}\text { As an antiseptic tool for wounds and bleeding of various } \\
\text { etiologies }\end{array}$ & $\begin{array}{c}\text { One of the most common over-the-counter drugs, } \\
\text { with a wide range of antimicrobial action }\end{array}$ \\
\hline Stability & At least 24-month shelf life & $\begin{array}{c}\text { Store at room temperature in a tightly packed } \\
\text { primary container }\end{array}$ \\
\hline \multirow[t]{2}{*}{ Packaging } & $\begin{array}{c}\text { Primary packaging: sterile cellophane-parchment } \\
\text { packaging/blister }\end{array}$ & \\
\hline & Secondary packaging: cardboard packaging & \\
\hline Appearance & $\begin{array}{c}\text { White, loose, structured sponges, soft, and without } \\
\text { foreign inclusions }\end{array}$ & \\
\hline Identification of API & & In accordance with the requirements of the USA \\
\hline Chlorhexidine digluconate & + & Pharmacopoeia, patents \\
\hline \multirow[t]{2}{*}{ Amino acids } & + & \\
\hline & Analysis & \\
\hline Chlorhexidine digluconate, $\%$ & $0.9-1.1$ & \\
\hline $\begin{array}{l}\text { In vitro degradation of sponges, } \\
\text { hours }\end{array}$ & No more than 50 hours & \\
\hline $\begin{array}{c}\text { Determination of water absorption, } \\
\%\end{array}$ & No less 2,800 & \\
\hline $\mathrm{pH}$ & $6.6-6.9$ & \\
\hline Sterility & Sterility of forms & \\
\hline
\end{tabular}

Table 2. CQAs.

\begin{tabular}{|c|c|c|}
\hline Quality indicators & Requirements & Justification \\
\hline $\begin{array}{l}\text { Time of complete dissolution/ } \\
\text { degree of degradation }\end{array}$ & $\begin{array}{l}\text { According to the } \\
\text { requirements QTPP }\end{array}$ & $\begin{array}{c}\text { These two indicators are interdependent and most characterize the quality of the } \\
\text { developed tool, as they allow us to predict the time of complete dissolution of } \\
\text { medical sponges and therefore are critical indicators }\end{array}$ \\
\hline $\begin{array}{c}\text { Percentage of water } \\
\text { absorption }\end{array}$ & $\begin{array}{l}\text { Must meet the established } \\
\text { requirements }\end{array}$ & $\begin{array}{l}\text { The percentage of water absorption affects the effectiveness of the developed } \\
\text { medical tool. The higher the percentage of water absorption is, the better and to a } \\
\text { greater extent the sponges will absorb the exudate }\end{array}$ \\
\hline Quantitative content of API & $\begin{array}{l}\text { Must meet the requirements } \\
\qquad( \pm 10 \%)\end{array}$ & $\begin{array}{c}\text { The concentration of API is a critical indicator of quality, as violation of the } \\
\text { tolerances of the quantitative content of API affects the pharmacological action and } \\
\text { quality }\end{array}$ \\
\hline
\end{tabular}

Table 4 presents the independent variables used as formulation factors. The experimental design matrix is shown in Table 5.

During designing the optimal composition of medical sponges, they were controlled by the following six indicators:

Study of $\mathbf{p H}$ change. The $\mathrm{pH}$ change in solution during degradation of the sponge was determined after 10,30, and 60 minutes and 12, 24, 36, 48, and 72 hours using a brand $\mathrm{pH}$ meter "MI-150." The average $\mathrm{pH}$ of each series was subjected to statistical processing.

Determination of water absorption. To the flatbottomed cup (preheated to $37^{\circ} \mathrm{C} \pm 1^{\circ} \mathrm{C}$ ) was added a simulation solution containing $8.398 \mathrm{~g} / 1$ sodium chloride and $0.278 \mathrm{~g} / \mathrm{l}$ anhydrous calcium chloride (the given proportion of ion content equal to the amount in human serum).
A piece of dry sponge $1 \times 1 \mathrm{~cm}^{2}\left(X_{0}\right)$ was preweighed and immersed in a simulation solution for 10 minutes. Then the sponge was removed and, after removing the surface moisture with filter paper, weighed $\left(X_{1}\right)$.

Water absorption ( $\%)$ is calculated as follows:

Water absorption $(\%)=\left(X_{1}-X_{0}\right) / X_{0} \times 100 \%$,

where $X_{0}$ is the mass of the sponge before absorption and $X_{1}$ is the mass of the sponge after absorption.

This method was used to model the water absorption curve and determine the time of complete dissolution (degradation). For this purpose, the sponge is weighed at certain intervals until complete dissolution.

In vitro degradation of sponges. Degradation can be determined by immersing a piece of sponge $\left(1 \times 1 \mathrm{~cm}^{2}\right)$ in 


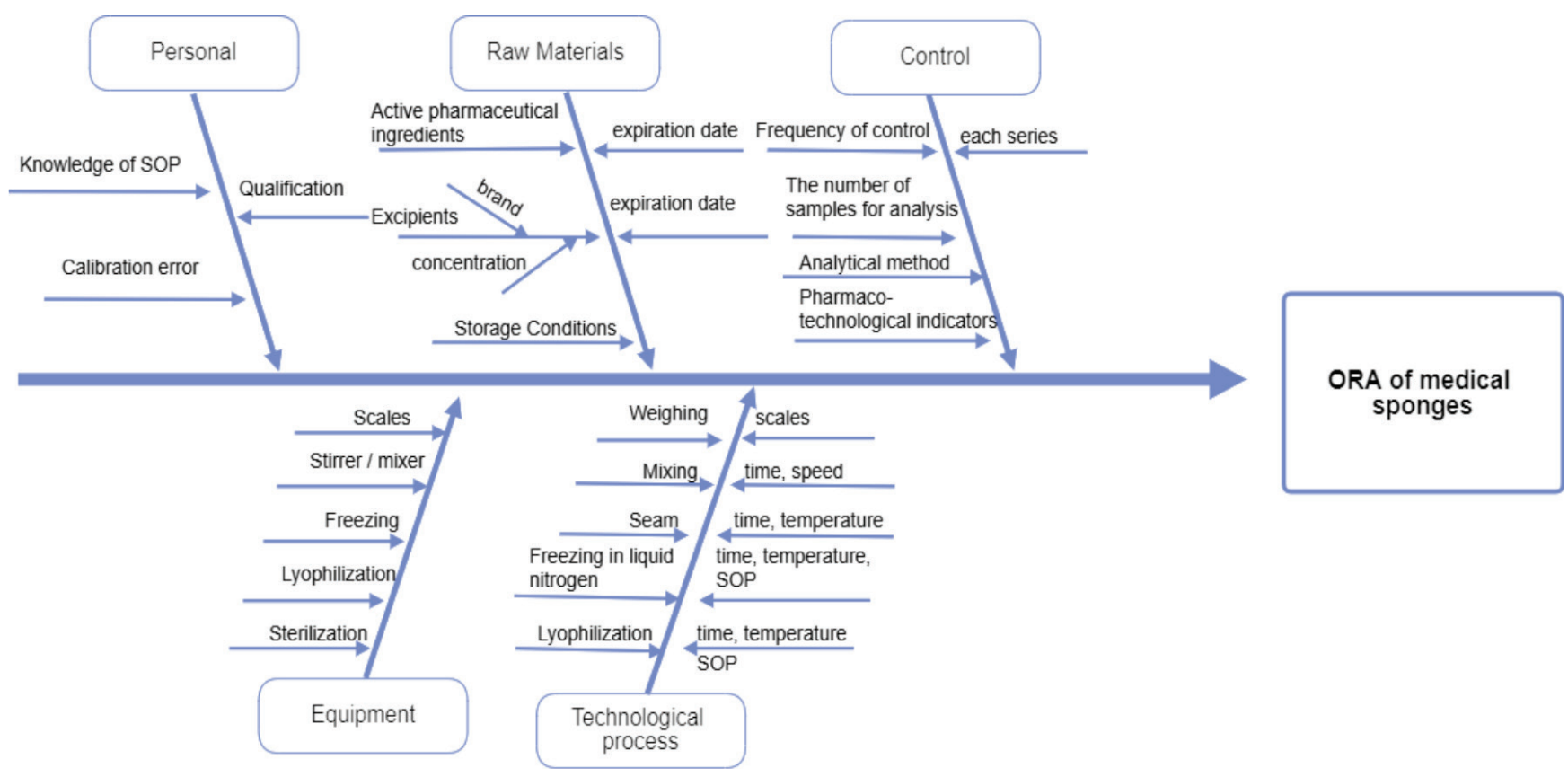

Figure 1. Ishikawa diagram.

Table 3. FMEA of risk assessment of medical sponges with chlorhexidine digluconate (1\%).

\begin{tabular}{|c|c|c|c|c|c|c|c|c|}
\hline $\mathrm{CPP} / \mathrm{CMC}$ & Potential failure mode & $\begin{array}{c}\text { Potential failure } \\
\text { effect }\end{array}$ & $\begin{array}{c}\text { Potential cause of } \\
\text { failure }\end{array}$ & Control method & $O$ & $S$ & $D$ & RPN \\
\hline $\begin{array}{l}\text { Drying time and } \\
\text { temperature }\end{array}$ & $\begin{array}{l}\text { Incorrect temperature } \\
\text { or change in drying } \\
\text { time }\end{array}$ & $\begin{array}{l}\text { Humidity after } \\
\text { lyophilization/ } \\
\text { hardness }\end{array}$ & $\begin{array}{l}\text { Device error and } \\
\text { human factor }\end{array}$ & $\begin{array}{l}\text { Appearance, } \\
\text { percentage of water } \\
\text { absorption, and } \\
\text { pore size }\end{array}$ & 1 & 5 & 2 & 10 \\
\hline $\begin{array}{l}\text { Homogeneity of the } \\
\text { composite mass }\end{array}$ & $\begin{array}{l}\text { Not matching } \\
\text { concentration, weight, } \\
\text { and thickness }\end{array}$ & $\begin{array}{l}\text { Hardness, fragility/ } \\
\text { humidity, and } \\
\text { mismatch of APIs } \\
\text { concentration }\end{array}$ & $\begin{array}{l}\text { Noncompliance with } \\
\text { technology }\end{array}$ & $\begin{array}{l}\text { In vitro degradation } \\
\text { and } \\
\text { percentage of water } \\
\text { absorption }\end{array}$ & 2 & 4 & 1 & 8 \\
\hline $\begin{array}{l}\text { Integrity of primary } \\
\text { packaging }\end{array}$ & Lack of sterility & $\begin{array}{l}\text { Microbiological } \\
\text { contamination }\end{array}$ & $\begin{array}{l}\text { Device error and } \\
\text { human factor }\end{array}$ & $\begin{array}{l}\text { Microbiological } \\
\text { control of the } \\
\text { sterility of the form }\end{array}$ & 3 & 5 & 3 & 45 \\
\hline
\end{tabular}

Table 4. Factors studied in the development of the optimal composition of medical sponge.

\begin{tabular}{|c|c|c|c|c|c|c|}
\hline \multirow[t]{2}{*}{ Factors } & \multirow{2}{*}{$\begin{array}{c}\text { Variation } \\
\text { interval }\end{array}$} & \multicolumn{5}{|c|}{ Level of factor } \\
\hline & & “- $\alpha "$ & “_” & “0” & “+” & $"+\alpha "$ \\
\hline$x_{1}:$ amount of medical gelatin, $\%$ & 1.0 & 0.32 & 1.0 & 2.0 & 3.0 & 3.68 \\
\hline$x_{2}:$ amount of propylene glycol, $\%$ & 0.5 & 0.16 & 0.5 & 1.0 & 1.5 & 1.84 \\
\hline$x_{3}:$ amount of formaldehyde, $\%$ & 0.04 & 0.008 & 0.035 & 0.075 & 0.115 & 0.142 \\
\hline
\end{tabular}

phosphate buffer solution with $\mathrm{pH} 7.4$ for 24 hours. The tests were carried out in an incubation chamber $\left(37^{\circ} \mathrm{C}\right)$. After 24 hours, the sponge is redried and the change in sponge mass is calculated. In vitro degradation of sponges calculated by the following formula:

$$
\text { In vitro degradation }(\%)=\left(X_{\mathrm{f}}-X_{\mathrm{s}}\right) / X_{\mathrm{s}} \times 100 \% \text {, }
$$

where $X_{\mathrm{f}}$ is the final mass of the sponge after drying and $X_{\mathrm{s}}$ is the initial mass of the sponge before immersion.

Appearance. Medical sponges were monitored for appearance and characteristic organoleptic properties (color, odor, and consistency), as well as for signs of physical instability (delamination, fragility, density, and surface homogeneity). 
Table 5. Experimental planning matrix and results of studying the characteristics of medical sponges.

\begin{tabular}{|c|c|c|c|c|c|c|c|c|c|}
\hline \multirow{2}{*}{ № } & \multicolumn{3}{|c|}{ Factors } & \multicolumn{6}{|c|}{ Reviews (indicators) } \\
\hline & $x_{1}$ & $x_{2}$ & $x_{3}$ & $y_{1}$ & $y_{2}$ & $y_{3}$ & $y_{4}$ & $y_{5}$ & $y_{6}$ \\
\hline 1 & + & + & + & 6.8 & 2,300 & 26 & 5 & 0.9 & 89 \\
\hline 2 & - & + & + & 6.6 & 2,400 & 62 & 4 & 0.9 & 31 \\
\hline 3 & + & - & + & 6.5 & 2,200 & 26 & 5 & 0.8 & 92 \\
\hline 4 & - & - & + & 6.8 & 2,400 & 63 & 5 & 0.9 & 38 \\
\hline 5 & + & + & - & 6.6 & 2,700 & 26 & 4 & 0.7 & 92 \\
\hline 6 & - & + & - & 6.5 & 2,750 & 68 & 5 & 0.6 & 45 \\
\hline 7 & + & - & - & 6.6 & 2,400 & 31 & 4 & 0.9 & 77 \\
\hline 8 & - & - & - & 6.7 & 2,300 & 69 & 5 & 0.9 & 35 \\
\hline 9 & $+\mathrm{L}$ & 0 & 0 & 6.7 & 2,600 & 26 & 4 & 0.6 & 109 \\
\hline 10 & $-\mathrm{L}$ & 0 & 0 & 6.6 & 2,000 & 96 & 4 & 0.6 & 25 \\
\hline 11 & 0 & $+\mathrm{L}$ & 0 & 6.8 & 2,850 & 52 & 5 & 0.9 & 49 \\
\hline 12 & 0 & $-\mathrm{L}$ & 0 & 6.6 & 2,850 & 48 & 5 & 0.9 & 50 \\
\hline 13 & 0 & 0 & $+\mathrm{L}$ & 6.9 & 1,980 & 41 & 4 & 1.3 & 59 \\
\hline 14 & 0 & 0 & $-\mathrm{L}$ & 6.4 & 2,800 & 49 & 4 & 0.8 & 54 \\
\hline 15 & 0 & 0 & 0 & 6.6 & 3,000 & 51 & 5 & 0.9 & 47 \\
\hline 16 & 0 & 0 & 0 & 6.6 & 2,800 & 47 & 5 & 0.8 & 51 \\
\hline 17 & 0 & 0 & 0 & 6.7 & 2,900 & 48 & 4 & 0.8 & 50 \\
\hline 18 & 0 & 0 & 0 & 6.6 & 3,100 & 49 & 5 & 0.9 & 49 \\
\hline 19 & 0 & 0 & 0 & 6.7 & 3,200 & 48 & 5 & 0.7 & 50 \\
\hline 20 & 0 & 0 & 0 & 6.8 & 3,150 & 47 & 5 & 0.8 & 51 \\
\hline
\end{tabular}

$y_{1}: \mathrm{pH}$ of sponges during degradation.

$y_{2}$ : Water absorption, \%.

$y_{3}$ : In vitro degradation of sponges, $\%$.

$y_{4}$ : Appearance, point.

$y_{5}:$ Thickness, $\mathrm{cm}$.

$y_{6:}$ Time of complete dissolution, hours.

Thickness. The thickness of the sponges was measured using a thickness gauge KI (GOST 6507-78) with an accuracy of $10 \mu \mathrm{m}$. The average thickness of the sponges of each series was subjected to statistical processing.

\section{RESULTS AND DISCUSSION}

\section{Risk assessment analysis}

According to ICH Q8, QTPP contains functions that have a direct relationship with the quality, safety, and efficacy attributes of the pharmaceutical. At the first stage of research, QTPP was developed taking into account the type of dosage form and technological features. CQA, which is determined by preliminary analysis, is the time of complete dissolution of the sponges and the percentage of water absorption.

The technological process of obtaining medical sponges consists of four main stages: preparation of the intermediate product of water extract from the xenoderm, mixing of components, freezing in a solution of liquid nitrogen, and lyophilization. Medical sponges were obtained using the process of lyophilization as one of the possible methods of drying, so an important point is to control the drying conditions (drying time and temperature), as risk components that generally affects the mechanical properties of sponges and made a negative impact on the time of complete dissolution and in vitro degradation of sponges. The ORA (all factors that may affect the quality of the final product, process, instruments, personnel, and analytical techniques) was analyzed using the Ishikawa diagram (Fig. 1).

$D o E$

Design-Expert 12.0 is an optimization software used for experimental design and statistical analysis. The planning matrix of this experiment and the results of studying the characteristics of medical sponges based on water extract from xenoderm and with $1 \%$ chlorhexidine digluconate are shown in Table 5 . The reliability of the experimental plan and the reliability of the obtained results were confirmed by the values of the statistical parameters of the ANOVA test.

When studying the three factors, the second-order model has the following form:

$$
\begin{aligned}
y= & b_{0} \mathrm{x}_{0}+b_{1} \mathrm{x}_{1}+b_{2} \mathrm{x}_{2}+b_{3} \mathrm{x}_{3}+b_{12} \mathrm{x}_{1} \mathrm{x}_{2}+b_{13} \mathrm{x}_{1} \mathrm{x}_{3}+b_{23} \mathrm{x}_{2} \mathrm{x}_{3} \\
& +b_{11} \mathrm{x}_{1}^{2+}+b_{22} \mathrm{x}_{2}^{2+}+b_{33} \mathrm{x}_{3}^{2} .
\end{aligned}
$$


Table 6. ANOVA indicating statistical parameters for the CQAs of medical sponges.

\begin{tabular}{|c|c|c|c|c|c|c|}
\hline \multirow{2}{*}{$\begin{array}{c}\text { Reviews } \\
\text { (indicators) }\end{array}$} & \multicolumn{6}{|c|}{ ANOVA parameters } \\
\hline & Source & Sum of squares & Df & Mean square & $F$-value & $p$-value \\
\hline \multirow[t]{5}{*}{$y_{1}, \mathrm{pH}$} & Model & 0.1735 & 6 & 0.0289 & 3.24 & 0.0358 \\
\hline & Residual & 0.1160 & 13 & 0.0089 & - & - \\
\hline & Lack of fit & 0.0827 & 8 & 0.0103 & $1.55^{\mathrm{a}}$ & 0.3266 \\
\hline & Pure error & 0.0333 & 5 & 0.0067 & - & - \\
\hline & Cor total & 0.2895 & 19 & - & - & - \\
\hline \multirow{5}{*}{$\begin{array}{c}y_{2} \text {, water } \\
\text { absorption, \% }\end{array}$} & Model & $2.201 E+06$ & 9 & $2.445 \mathrm{E}+05$ & 6.42 & 0.0038 \\
\hline & Residual & $3.806 \mathrm{E}+05$ & 10 & $38,059.84$ & - & - \\
\hline & Lack of fit & $2.618 \mathrm{E}+05$ & 5 & $52,369.68$ & $2.21^{\mathrm{a}}$ & 0.2029 \\
\hline & Pure error & $1.188 \mathrm{E}+05$ & 5 & $23,750.00$ & - & - \\
\hline & Cor total & $2.581 \mathrm{E}+06$ & 19 & - & - & - \\
\hline \multirow{5}{*}{$\begin{array}{c}y_{3}, \text { in vitro } \\
\text { degradation of } \\
\text { sponges, } \%\end{array}$} & Model & $5,713.14$ & 9 & 634.79 & 43.06 & $<0.0001$ \\
\hline & Residual & 147.41 & 10 & 14.74 & - & - \\
\hline & Lack of fit & 136.08 & 5 & 27.22 & $12.01^{\mathrm{a}}$ & 0.0082 \\
\hline & Pure error & 11.33 & 5 & 2.27 & - & - \\
\hline & Cor total & $5,860.55$ & 19 & - & - & - \\
\hline \multirow[t]{5}{*}{$y_{5}$, thickness, $\mathrm{cm}$} & Model & 0.3908 & 9 & $5.551 \mathrm{E}-17$ & 7.797E-15 & 1.0000 \\
\hline & Residual & 0.0712 & 10 & 0.0071 & - & - \\
\hline & Lack of fit & 0.0429 & 5 & 0.0086 & $1.51^{\mathrm{a}}$ & 0.3303 \\
\hline & Pure error & 0.0283 & 5 & 0.0057 & - & - \\
\hline & Cor total & 0.4620 & 19 & - & - & - \\
\hline \multirow{5}{*}{$\begin{array}{c}y_{6} \text {, time of } \\
\text { complete } \\
\text { dissolution, } \mathrm{h}\end{array}$} & Model & $9,636.28$ & 9 & $1,070.70$ & 118.61 & $<0.0001$ \\
\hline & Residual & 90.27 & 10 & 9.03 & - & - \\
\hline & Lack of fit & 78.94 & 5 & 15.79 & $6.97^{\mathrm{a}}$ & 0.0264 \\
\hline & Pure error & 11.33 & 5 & 2.27 & - & - \\
\hline & Cor total & $9,726.55$ & 19 & - & - & - \\
\hline
\end{tabular}

${ }^{a}$ Not significant.

The statistical significance of the coefficients and the adequacy of the models were checked using the F-criterion. The nature of the influence of the studied factors was determined by the values and signs of the regression coefficients. The results of the experiment are shown in Table 6.

The relationship between the studied factors on the $\mathrm{pH}$ of medical sponges, after ignoring the insignificant terms, is described by the following regression equation:

$$
y_{1}=6.65+0.083 x_{3}+0.09 x_{1} x_{2} .
$$

Only statistically significant coefficients are included in this and other regression equations below. The regression equation shows the statistical significance of $x_{3}$ (amount of formaldehyde), as well as the interaction of factors $x_{1}$ and $x_{2}$ (gelatin and propylene glycol content). The coefficients $b_{1}, b_{2}, b_{13}, b_{23}, b_{11}, b_{22}$, and $b_{33}$ were statistically insignificant in the regression equation.

For significant coefficients of pair interactions, the interpretation of the regression equation is carried out using a graph. The effect of formaldehyde on the $\mathrm{pH}$ of medical sponges, which was studied during the degradation of sponges, is shown in Figure 2. With an increasing amount of formaldehyde, more than $0.075 \%$ in the composition of the sponges increases the $\mathrm{pH}$ value.
As seen in Table 6, the Model $F$-value of 3.24 implies that it is significant. There is only a $3.58 \%$ chance that an $F$-value this large could occur due to the noise. $p$-values less than 0.0500 indicate model terms are significant. In this case, $\mathrm{C}$ and $\mathrm{AB}$ are significant model terms.

The most significant factor influencing percentages of water absorption is factor $\mathrm{x}_{3}$, the amount of formaldehyde. The coefficients $b_{1}, b_{2}, b_{12}, b_{13}, b_{23}, b_{34}$, and $b_{22}$ were statistically insignificant in the regression equation.

The equation of polynomial regression for the percentage of water absorption after ignoring the insignificant terms is presented as follows:

$$
y_{2}=3,026.65-163.22 x_{3}-267.09 x_{1}^{2}-235.28 x_{3}^{2} \text {. }
$$

The effect of formaldehyde on the percentage of water absorption in the composition of medical sponges is shown in Figure 3. The analysis revealed one type of dependence of the percentage of water absorption on the amount of formaldehyde because when the amount of formaldehyde increases to $0.075 \%$, the percentage of water absorption increases and a further increase in its amount to $0.115 \%$ leads to a negative result.

The adequacy of the model describing the influence of the studied factors on the percentage of water absorption was 


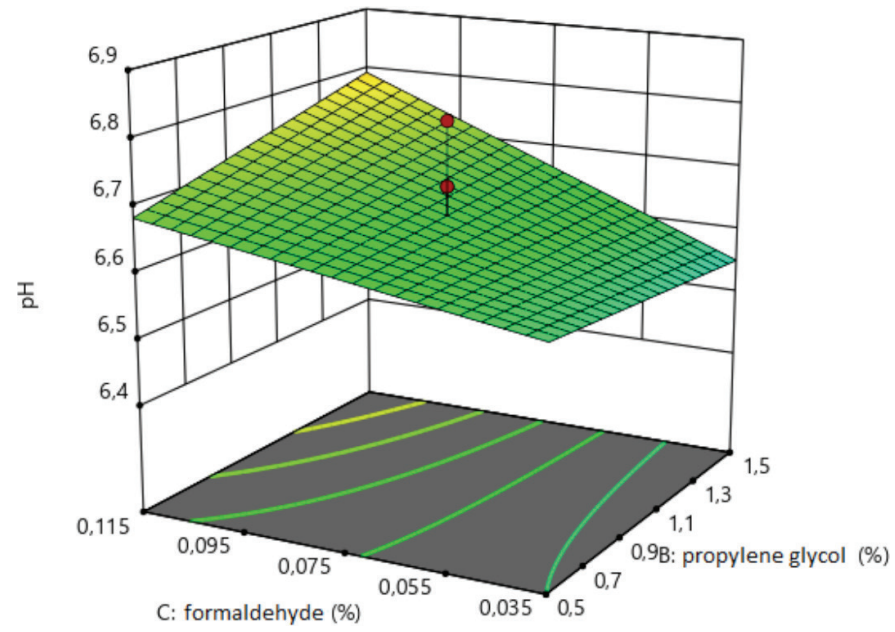

Figure 2. Surface response plot for the $\mathrm{pH}$ of sponges during degradation.

tested using the $F$-test. As seen in Table 6, the model $F$-value of 6.42 implies that it is significant. There is only a $0.38 \%$ chance that an $F$-value this large could occur due to the noise. $p$-values less than 0.0500 indicate that model terms are significant.

The relationship between the studied factors and the degree of degradation of medical sponges, after excluding insignificant coefficients, is described by the following regression equation:

$$
y_{3}=48.52-19.82 x_{1}-2.23 x_{3}+3.24 x_{1}^{2}-2.41 x_{3}^{2} .
$$

As the values of the coefficients show, the most significant factors influencing the percentage of degradation were factors $x_{1}$, the amount of medical gelatin, and $x_{3}$, the amount of formaldehyde. The coefficients $b_{2}, b_{12}, b_{13}, b_{14}, b_{23}$, and $b_{22}$ were statistically insignificant in the regression equation. According to the data in Table 6, the Model $F$-value of 43.06 implies that it is significant. There is only a $0.01 \%$ chance that an $F$-value this large could occur due to the noise. $p$-values less than 0.0500 indicate that model terms are significant.

The influence of the amount of medical gelatin and formaldehyde on the degree of in vitro degradation of medical sponges is shown in Figure 4. The analysis revealed the types of the dependence of the degree of degradation of sponges on the studied factors $(\mathrm{x} 1 ; \mathrm{x} 3)$, which indicate that, with increasing gelatin to $3 \%$, the degree of degradation decreases, and therefore, the sponges will not dissolve during a long time. The concentration of medical gelatin directly affects the degree of degradation, namely from $26 \%$ to $96 \%$. As for the effect of formaldehyde, it to a lesser extent than medical gelatin affects the degree of degradation, but with an increase in the amount of formaldehyde to $0.115 \%$, the degree of degradation decreases.

The influence of factors on the appearance $\left(y_{4}\right)$ of developed sponges was evaluated on a 5-point scale, as in the analysis of variance. The regression equation has the following form:

$$
y_{4}=4.8 \text {. }
$$

Thus, we can characterize that Fexp adequately reproduces the model; none of the studied factors within the studied intervals does affect the appearance of the developed medical sponges.

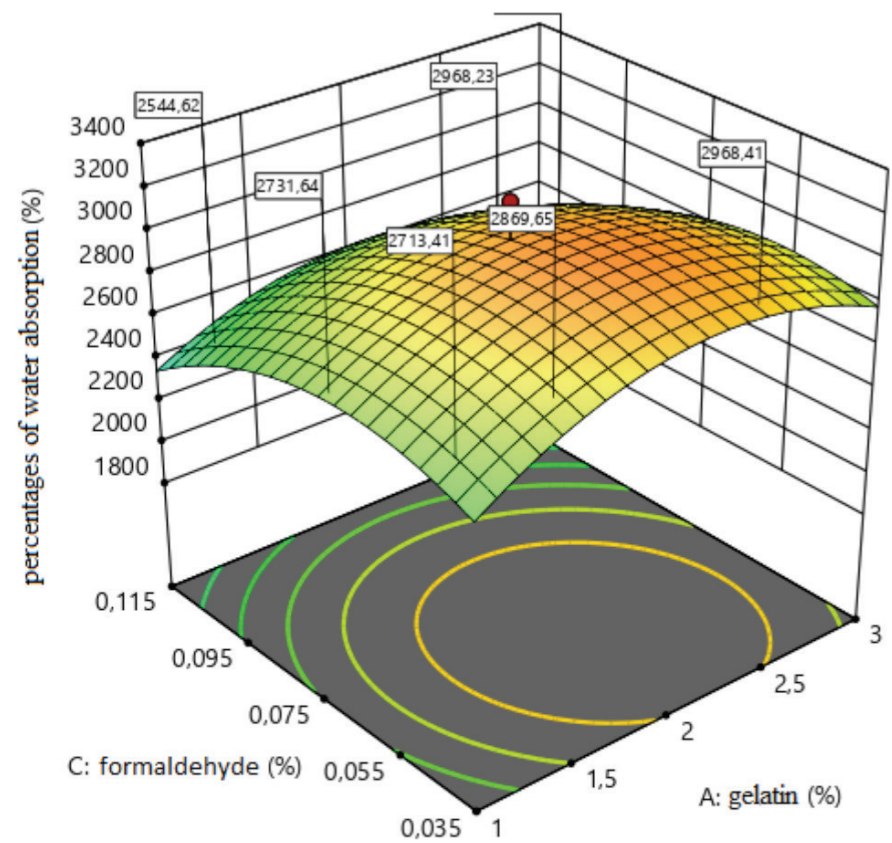

Figure 3. Surface response plot for the percentages of water absorption (\%).

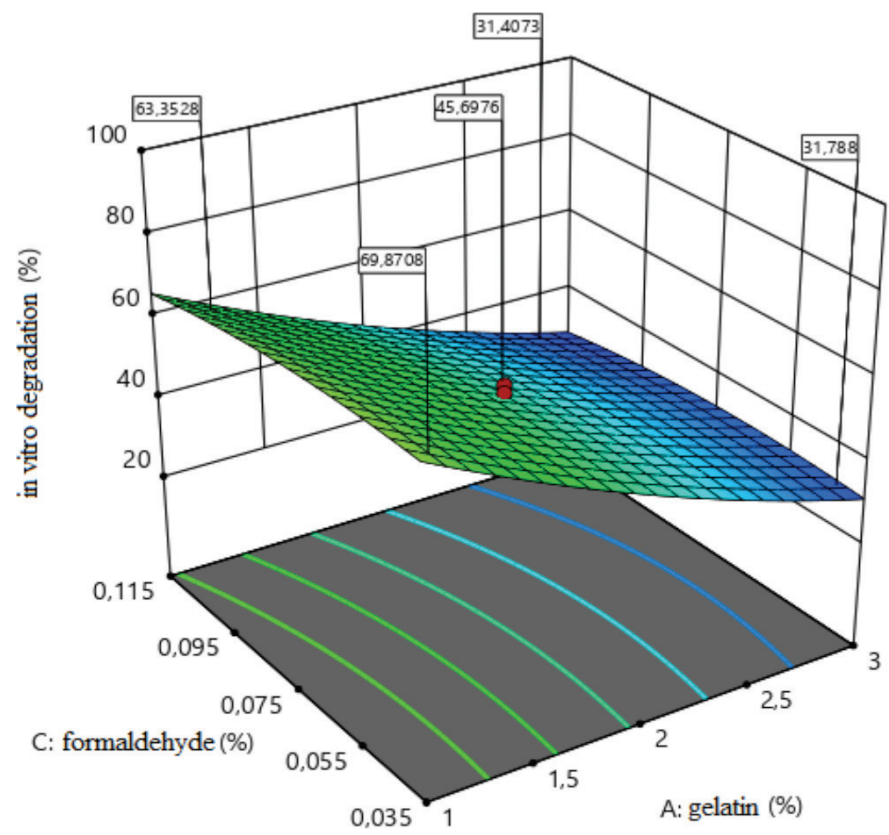

Figure 4. Surface response plot for the degree of in vitro degradation (\%).

The relationship between the studied factors and the thickness of medical sponges, after excluding insignificant coefficients, is described by the following regression equation:

$$
\begin{aligned}
y_{5}= & 0.82+0.09 x_{3}+0.07 x_{2} x_{3}-0.08 x_{1}^{2}+0.07 x_{3}^{2}(\mathrm{~F} \exp = \\
& 0.90) .
\end{aligned}
$$

As the values of the coefficients show, the most significant factor influencing the thickness of the sponges is factor $x_{3}$, the amount of formaldehyde. The following coefficients were statistically insignificant in the regression equation: $b_{1}, b_{2}, b_{12}$, 


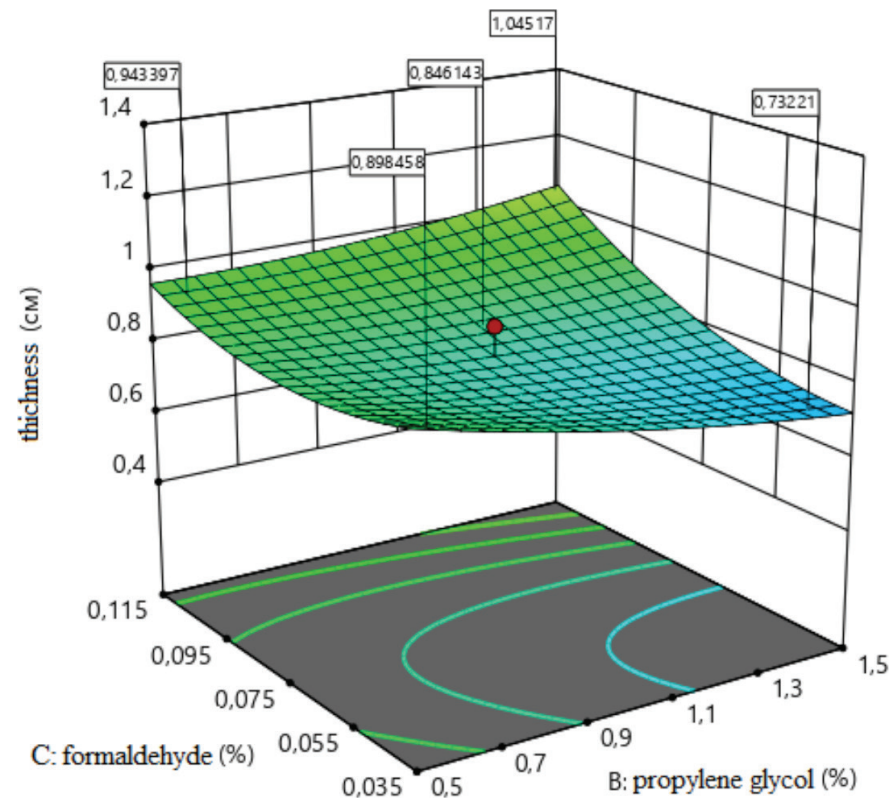

Figure 5. Surface response plot for the thickness of the sponges (cm).

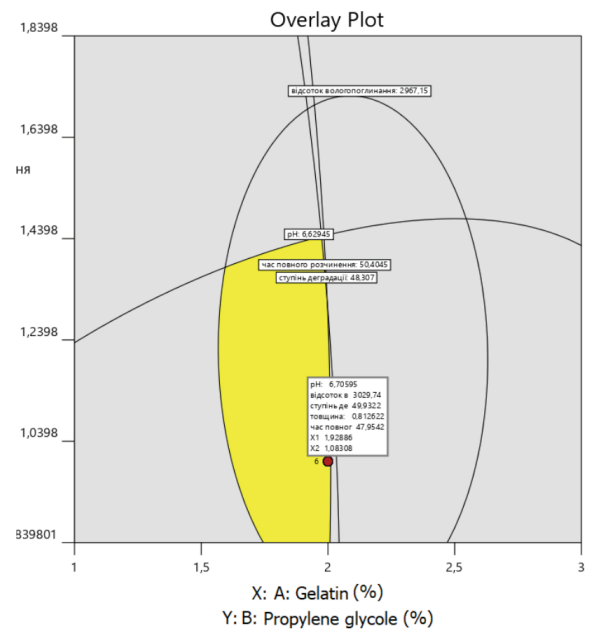

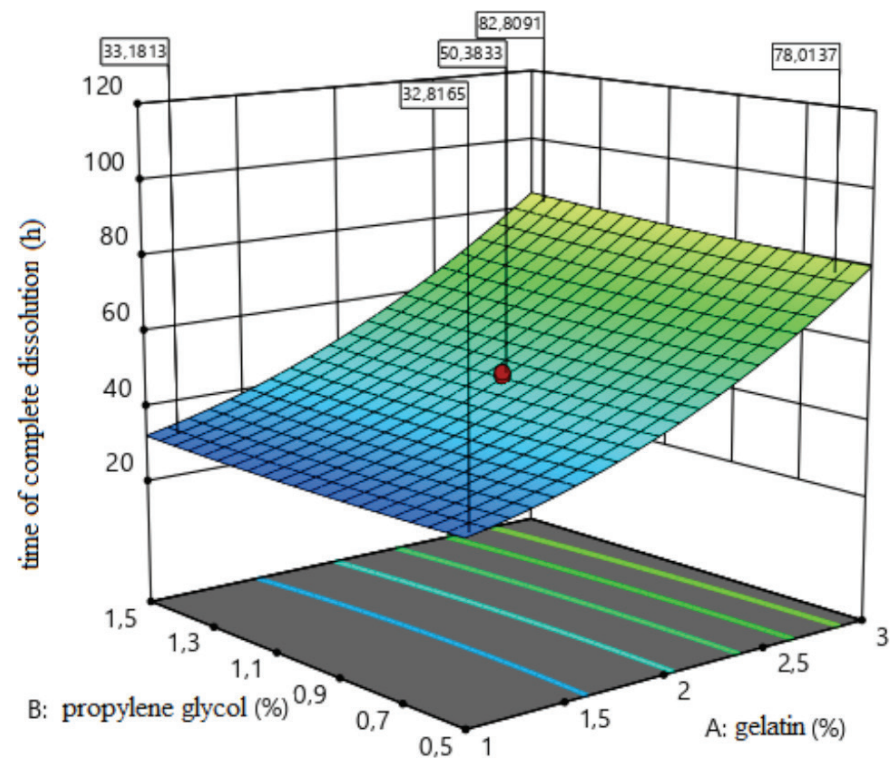

Figure 6. Surface response plot for the time of complete dissolution (hours).
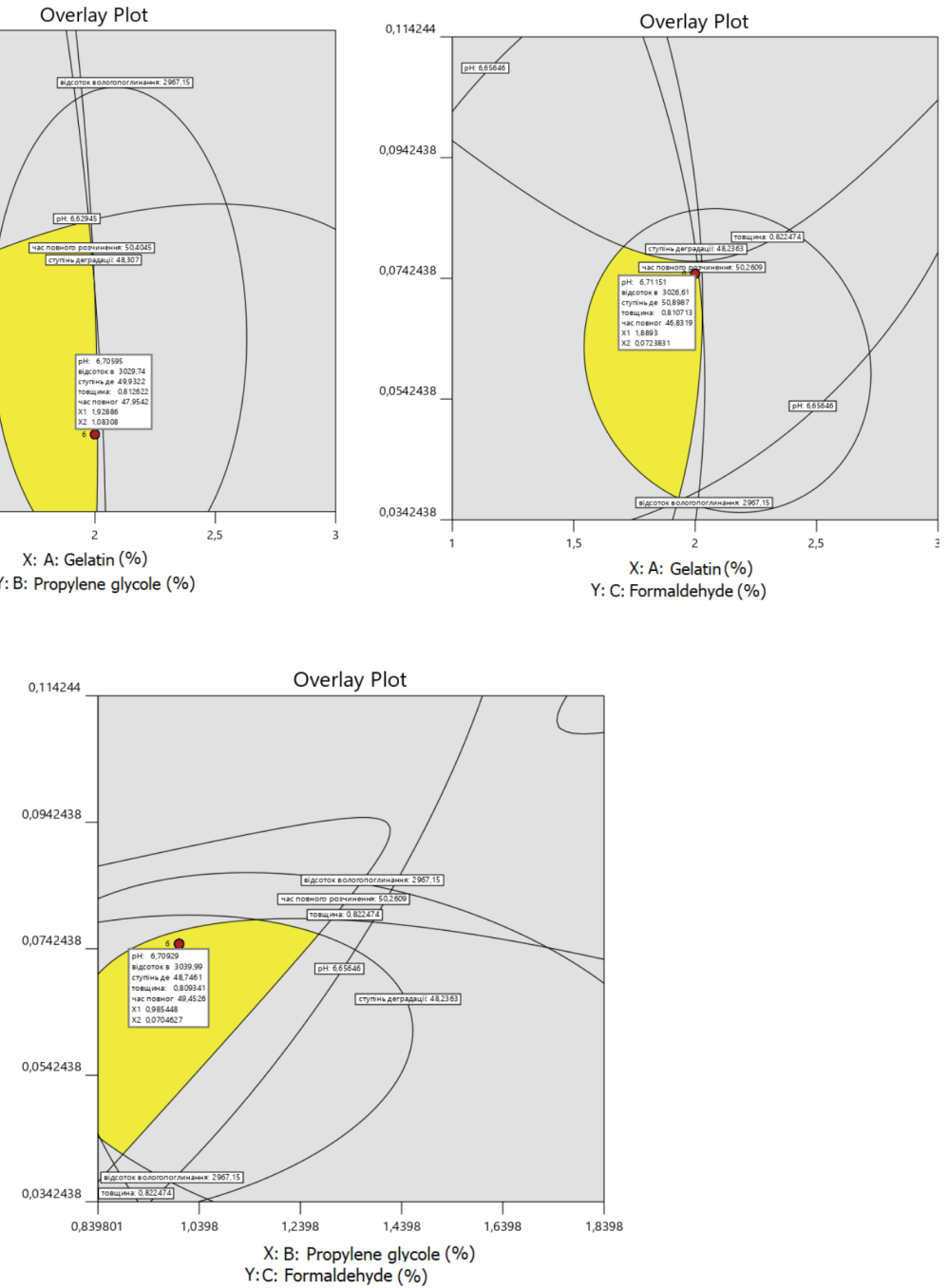

Figure 7. Optimum formulation of medical sponges. 
$b_{13}, b_{14}, b_{23}$, and $b_{22}$. The $F$-value model of 6.10 implies that it is significant (Table 6 ). There is only a $0.46 \%$ chance that an $F$-value this large could occur due to the noise.

The effect of formaldehyde on the thickness of medical sponges is shown in Figure 5. As a result of the analysis, the type of dependence of sponge thickness on the amount of formaldehyde was established, which indicates that, with an increasing amount of formaldehyde $\left(x_{3}\right)$ to the maximum value, the thickness of sponges increases. It leads to increased porosity and to the formation of sponges with larger sizes pores. Thus, the concentration of formaldehyde affects the thickness of medical sponges; namely with increasing concentration from $0.075 \%$ to $0.142 \%$, the thickness of the sponges increases.

The relationship between the studied factors and the time of complete dissolution of medical sponges, after excluding insignificant coefficients, is described by the following regression equation:

$$
\begin{aligned}
y_{6}= & 49.53+25.06 x_{1}+2.87 x_{1} x_{3}-4.37 x_{2} x_{3}+7.01 x_{1}^{2}+ \\
& 3.30 x_{3}{ }^{2} .
\end{aligned}
$$

The factor that most affects the time of complete dissolution is the amount of medical gelatin (factor $x_{1}$ ). The coefficients $b_{2}, b_{3}, b_{12}$, and $b_{22}$ were statistically insignificant in this regression equation. The model $F$-value of 118.61 implies that it is significant (Table 6). There is only a $0.01 \%$ chance that an $F$-value this large could occur due to the noise.

The effect of the amount of medical gelatin in the composition of medical sponges at the time of complete dissolution is shown in Figure 6. The analysis revealed the type of dependence of the time of complete dissolution of sponges on the content of factor $x_{1}$, which indicates that reducing the amount of medical gelatin to $0.32 \%$ accelerates the dissolution of sponges, and a further increase in the concentration causes slow, gradual dissolution.

Based on the obtained results of statistical processing of experimental data and the obtained regression equations to study the influence of factor levels on the characteristics of medical sponges, as well as based on pharmaco-technological quality indicators, the optimal composition was determined using DesignExpert 12.0.0 for the three factors studied.

The optimal composition of medical sponges was selected on the basis of the limitations of pharmaco-technological parameters established for dependent variables: $y_{1}$ (6.6-6.9), $y_{2}$ $(2800 \%-3100 \%), y_{3}(45 \%-55 \%), y_{5}(0.8-0.9 \mathrm{~cm})$, and $y_{6}(46-50$ hours) (Fig. 7).

Based on the obtained results, the optimal composition of medical sponges is proposed: the concentration of gelatin, $2.0 \%$; propylene glycol, $1.0 \%$; and formaldehyde, $0.075 \%$.

\section{CONCLUSION}

Using the concept of quality by design, the desired quality target product profile, critical quality attributes, risk assessment by failure mode effects analysis were analyzed. In order to determine the optimal composition of sponges and identify factors that may affect their quality characteristics, 20 experimental samples of medical sponges were developed and their pharmaco-technological parameters were studied. The experiment identified two main risks that affect quality, namely the duration of lyophilization and drying temperature. It was determined that the number of excipients affects the pharmaco- technological parameters, so the most optimal is the concentration of gelatin at the " 0 " point, propylene glycol at the upper "+" point, and formaldehyde at the " 0 " point of the plan. The developed medical sponges are stable when stored at a temperature not exceeding $25^{\circ} \mathrm{C}$ in sterile packaging for 2 years.

\section{AUTHOR CONTRIBUTIONS}

All authors made substantial contributions to conception and design, acquisition of data, or analysis and interpretation of data; took part in drafting the article or revising it critically for important intellectual content; agreed to submit to the current journal; gave final approval of the version to be published; and agree to be accountable for all aspects of the work. All the authors are eligible to be an author as per the international committee of medical journal editors (ICMJE) requirements/guidelines.

\section{FUNDING}

There is no funding to report.

\section{CONFLICTS OF INTEREST}

The authors report no financial or any other conflicts of interest in this work.

\section{ETHICAL APPROVALS}

This study does not involve experiments on animals or human subjects.

\section{PUBLISHER'S NOTE}

This journal remains neutral with regard to jurisdictional claims in published institutional affiliation.

\section{REFERENCES}

Azuma K, Izumi R, Osaki T, Ifuku S, Morimoto M, Saimoto H, Minami S, Okamoto Y. Chitin, chitosan, and its derivatives for wound healing: old and new materials. J Funct Biomater, 2015; 6(1):104-42.

Beg S, Rahman M, Kohli K. Quality-by-design approach as a systematic tool for the development of nanopharmaceutical products. Drug Discov Today, 2019; 24(3):717-25.

Budniak L, Vasenda M, Marchyshyn S, Kurylo Kh. Determination of the optimum extraction regime of reducing compounds and flavonoids of Primula denticulate Smith leaves by a dispersion analysis. Pharmacia, 2020; 67(4):373-8.

Demchuk M, Taras G, Chubka M, Stechyshyn I. Greco-Latin square design for selection of excipients in the development of metformin orodispersible tablets. Asian J Pharm, 2018; 12(3):211-20.

ICH. International Conference on Harmonisation of Technical Requirements for Registration of Pharmaceuticals for Human Use, Pharmaceutical Development, Q8(R2). ICH, 2009.

ICH. International Conference on Harmonisation of Technical Requirements for Registration of Pharmaceuticals for Human Use, Quality Risk Management, Q9. ICH, 2005.

ICH. International Conference on Harmonisation of Technical Requirements for Registration of Pharmaceuticals for Human Use, Pharmaceutical Quality Systems, Q10. ICH, 2008

Konstantelias AA, Polyzos KA, Falagas ME. GentamicinCollagen sponges for the prevention of surgical site infections: a metaanalysis of randomized controlled trials. Surg Infect, 2016; 17(5):601-9.

Leonard J, Zietlow J, Morris D, Berns K, Eyer S, Martinson $\mathrm{K}$, Jenkins D, Zietlow S. A multi-institutional study of hemostatic gauze and tourniquets in rural civilian trauma. J Trauma Acute Care Surg, 2016; 81(3):441-4.

Liu JY, Li Y, Hu Y, Cheng G, Ye E, Shen C, Xu FJ. Hemostatic porous sponges of cross-linked hyaluronic acid/cationized dextran by 
one self-foaming process. Mater Sci Eng C Mater Biol Appl, 2018; 83:160-8.

Lytvynyuk SO, Volkov KS, Nebesna ZM. Morphofunctional modifications of neurocytes of the rat hippocampal $\mathrm{CA}_{3}$ area after experimental thermal trauma. Neurophysiology, 2016; 48:399-406.

Marushchak M, Krynytska I, Milevska L, Miz A, Mialiuk O. The changes of activity of effector caspase cascade components in case of alimentary obesity in rats. Bangladesh J Med Sci, 2017; 16(2):252-8.

Mogal V. A review on quality by design. Pharm Biol Eval, 2016; 3:313-9.

Ohage E, Iverson R, Krummen L, Taticek R, Vega M. QbD implementation and post approval lifecycle management (PALM). Biologicals, 2016; 44(5):332-40.

Patwardhan DM, Amrutkar SS, Kotwal TS, Wagh MP. Application of quality by design to different aspects of pharmaceutical technologies. Int J Pharm Sci Res, 2017; 8(9):3649-62.

Pavliuk B, Chubka M, Hroshovyi T, Stechyshyn I. Characteristics of structured medical hemostatic sponges as a medical devices for stop bleeding and for close the wound. Polski Merkuriusz Lekarski, 2020a; 48(288):422-6.

Pavliuk B, Stechyshyn I, Kramar S, Chubka M, Hroshovyi T. Therapeutic efficacy of the developed gel "Xeliogel" on a burn wound model in rats. Polski Merkuriusz Lekarski, 2020b; 48(287):331-4.

Politis N, Colombo S, Colombo P, Rekkas M. Design of experiments (DoE) in pharmaceutical development. Drug Dev Ind Pharm, 2017; 43(6):889-901.

Porfire A, Muntean DM, Rus L, Sylvester B, Tomuţă I. A quality by design approach for the development of lyophilized liposomes with simvastatin. Saudi Pharm J, 2017; 25(7):981-92.
Suciu S, Iurian S, Bogdan C, Iovanov R, Rus L, Moldovan M, Tomuță I. QbD approach in the development of oral lyophilisates with ibuprofen for paediatric use. Farmacia, 2018; 66(3):514-8.

Sylvester B, Porfire A, Muntean DM, Vlase L, Lupuţ L, Licarete E, Sesarman A, Alupei MC, Banciu M, Achim M, Tomuță I. Optimization of prednisolone-loaded long-circulating liposomes via application of Quality by Design (QbD) approach. J Liposome Res, 2018; 28(1):49-61.

Tefas LR, Rus LM, Achim M, Vlase L, Tomuță I. Application of the quality by design concept in the development of Quercetin-loaded polymeric nanoparticles. Farmacia, 2028; 66(5):798-810.

Vons B, Tryhubchak O, Grochovuy T, Chubka M, Bihunyak V. Research of powders of the cryolyophilized xenoderm of porcine skin. Int J Green Pharm, 2018; 12(3):657-64.

\section{How to cite this article:}

Pavliuk B, Chubka M, Hroshovyi T, Demchuk M, Stechyshyn I. The development of biodegradable hemostatic and absorbable sponges containing chlorhexidine digluconate and their in vitro characterization-A QbD approach. J Appl Pharm Sci, 2022; 12(02):056-065. 